\title{
Analysis of Factors That Influence The Incidence of Anemia In Teenager at Al Ma'ruf Islamic Boarding School Kediri
}

\author{
Dessy Lutfiasari*, Galuh Pradian Yanuaringsih \\ Faculty of Health Sciences, Kadiri University, Indonesia \\ *dessylutfiasari@unik-kediri.ac.id
}

\begin{abstract}
Fulfilment of optimal balance nutrition will be affected by the health and reproductive system on the teenager. The main problem at that period is an iron deficiency or anaemia. Based on preliminary studies in Al Ma'ruf Islamic Boarding School there were 28 teenagers $(29,1 \%)$ from 96 had anaemia. The data showed that there is still a high incident in Al Ma'ruf Islamic Boarding School. This research aims to analyze factors that influence the incidence of anaemia in teenager at Al Ma'ruf Islamic Boarding School Kediri. A study design used in this research is correlational analytic with a cross-sectional approach. The population and sample in this study were all teenagers in Al Ma'ruf Islamic Boarding School in Kediri as many as 96 people. The sampling technique used in this research is the total population.

Measurement methods used questionnaire and data analysis using Rho spearman and multiple logistic regression. The result of this research showed factor that influenced the incident of anaemia are age ( $p$ value $=0,017$; OR $=7,118)$, knowledge of nutrition $(p$ value $=0,006 ; \mathrm{OR}=0,230$ ) and nutritional status ( $\mathrm{p}$ value $=0,000 ; \mathrm{OR}=0,025$ ). Age is the most affected factor that increasing the incident of anaemia. Physical activity (p value $=0,604)$ and length of menstruation ( $p$ value $=0,071$ ) are not correlated with the incidence of anaemia.
\end{abstract}

Keywords: Age, Anaemia, Knowledge of Nutrition, Length of Menstruation, Nutritional Status, Physical Activity 


\section{STRADA Jurnal Ilmiah Kesehatan}

DOI: $10.30994 /$ sjik.v9i2.460

ISSN: 2252-3847 (print); 2614-350X (online)

Vol.9 No.2 November 2020 Page.1291-1299

\section{BACKGROUND}

The health of a teenager is one determinant of health development. They will be the next generation of the country because at that time is the beginning of the reproductive cycle. Fulfilment of optimal balance nutrition will be affected by the health and reproductive system. The main problem at that period is an iron deficiency or anaemia. Iron is needed by the body because it is the oxygen carrier needed by the body (Abioye \& Fawzi, 2020).

Anaemia is a condition where either the number of red blood cells or their oxygencarrying capacity is inadequate to meet an individual's physiologic need (Wall, Gillies, \& Zealand, 2019). Anaemia due to iron deficiency has been one of the leading factors affecting the global burden of disease. Nearly one -a quarter of the world's population is affected by anaemia, with over one and a half billion people affected worldwide (Beck \& Zealand, 2016).

Anaemia is common in developing country such as in Indonesia (Beck \& Zealand, 2016). Iron deficiency to be a common problem in the teenager. 14\% of 11-14 years old girls and $27 \%$ of 15-18 years old girls had low ferritin levels (suggesting low iron stores) and $4 \%$ and $9 \%$ respectively, were estimated to suffer from iron deficiency anaemia (Pennesi et al., 2019) Based on Riskesdas at 2013 showed that there is the increasing number of anaemia at a teenager from $37,1 \%$ to $48,9 \%$ at 2018 (RISKESDAS, 2018). That number is higher than the incident in the world approximately $27 \%$ in (Wall et al., 2019).

Based on preliminary studies in Al Ma'ruf Islamic Boarding School there were 28 teenagers $(29,1 \%)$ from 96 had anaemia. From 28 teenagers only $1 \%$ had severe anaemia. The data showed that there is still a high incident in Al Ma'ruf Islamic Boarding School.

Anaemia may be caused by genetic factors like hemoglobinopathies, infections (e.g. malaria, tuberculosis, human immune deficiency virus and intestinal helminths), blood loss (e.g. menstruation) and chronic conditions (e.g. cancer). Micronutrient deficiencies including vitamin A, vitamin B12, folate and copper also increase the risk of anaemia, but the level at which they contribute to anaemia risk is not clear (Beck \& Zealand, 2016). Indirect causes of anaemia are socioeconomic conditions, food intake and nutritional status, morbidity, health care, age and sex (Kotwal, 2016). Apart from nutritional deficiencies, anaemia is associated with lifestyle such as obesity and diabetes mellitus (Shubham et al., 2020).

Anaemia is a widespread public health problem with consequences for individuals and their physical, social and economic development (Shamah, Villalpando, \& Cruz, 2017). Anaemia causes physical impairment, work performance, decreased infectious diseases (Villalpando, 2016).

Strategies to prevent anaemia have focussed on infection control, improvement of nutritional status, increasing dietary iron intake and bioavailability through dietary education, food fortification and iron supplementation (Beck \& Zealand, 2016). Beside of that food preparation and diet modification also used to prevent anaemia (Kotwal, 2016).

\section{METHODS}

A study design used in this research is correlational analytic with the cross-sectional approach. The population and sample in this study were all teenagers in Al Ma'ruf Islamic Boarding School in Kediri as many as 96 people. The sampling technique used in this research is the total population. The data collection process was carried out starting in March 2020. Research Variables are the independent variable and dependent variable. The dependent variable is an incident of anaemia. Independent variable in this research is age, 


\section{STRADA Jurnal Ilmiah Kesehatan}

DOI: $10.30994 /$ sjik.v9i2.460

ISSN: 2252-3847 (print); 2614-350X (online)

Vol.9 No.2 November 2020 Page.1291-1299

knowledge of nutrition, physical activity, nutritional status and length of menstruation. Measurement methods used questionnaire and data analysis using Rho spearman and multiple logistic regression.

\section{RESULT}

The Relationship between age and incidence of anaemia in teenager

Table 1 The relationship between age and the incidence of anaemia in the teenager

\begin{tabular}{|c|c|c|c|c|c|c|c|c|c|c|c|}
\hline \multirow{3}{*}{ Age } & \multicolumn{10}{|c|}{ Incidence of anaemia } & \multirow{3}{*}{$\mathrm{p}$ value } \\
\hline & \multicolumn{2}{|c|}{ Not anaemia } & \multicolumn{2}{|c|}{ Mild anaemia } & \multicolumn{2}{|c|}{$\begin{array}{c}\text { Moderate } \\
\text { anaemia }\end{array}$} & \multicolumn{2}{|c|}{$\begin{array}{c}\text { Severe } \\
\text { anaemia }\end{array}$} & \multicolumn{2}{|c|}{ Total } & \\
\hline & $\mathrm{N}$ & $\%$ & $\mathrm{~N}$ & $\%$ & $\mathrm{~N}$ & $\%$ & $\mathrm{~N}$ & $\%$ & $\mathrm{~N}$ & $\%$ & \\
\hline Early teen & 0 & 0 & 0 & 0 & 0 & 0 & 0 & 0 & 0 & 0 & \multirow{4}{*}{0,017} \\
\hline Middle teen & 26 & 27,1 & 4 & 4,2 & 0 & 0 & 0 & 0 & 30 & 31,3 & \\
\hline Late teen & 42 & 43,8 & 19 & 19,8 & 4 & 4,2 & 1 & 1 & 66 & 68,8 & \\
\hline Amount & 68 & 70,8 & 23 & 24 & 4 & 4,2 & 1 & 1 & 96 & 100 & \\
\hline
\end{tabular}

Based on table 1 showed that almost half of the respondents $(43,8 \%)$ did not have anaemia in late teenage. The highest incidence of anaemia was mild anaemia in late teenage $(19,8 \%)$. The result of a statistic test using rho spearman obtained that $p$-value is 0,017 which p-value $<0,05$ that can be concluded if there are the relationship between age and the incidence of anaemia in a teenager in $\mathrm{Al} \mathrm{Ma'ruf} \mathrm{Islamic} \mathrm{Boarding} \mathrm{School} \mathrm{Kediri} \mathrm{in}$ 2020 .

\section{The relationship between knowledge of nutrition and the incidence of anaemia in a teenager}

Table 2 The relationship between knowledge of nutrition and the incidence of anaemia in a teenager

\begin{tabular}{|c|c|c|c|c|c|c|c|c|c|c|c|}
\hline \multirow{3}{*}{$\begin{array}{l}\text { Knowledge } \\
\text { of nutrition }\end{array}$} & \multicolumn{10}{|c|}{ Incidence of anaemia } & \multirow{3}{*}{$\mathrm{p}$ value } \\
\hline & \multicolumn{2}{|c|}{ Not anaemia } & \multicolumn{2}{|c|}{ Mild anaemia } & \multicolumn{2}{|c|}{$\begin{array}{l}\text { Moderate } \\
\text { anaemia }\end{array}$} & \multicolumn{2}{|c|}{$\begin{array}{c}\text { Severe } \\
\text { anaemia }\end{array}$} & \multicolumn{2}{|c|}{ Total } & \\
\hline & $\mathrm{N}$ & $\%$ & $\mathrm{~N}$ & $\%$ & $\mathrm{~N}$ & $\%$ & $\mathrm{~N}$ & $\%$ & $\mathrm{~N}$ & $\%$ & \\
\hline Good & 15 & 15,6 & 11 & 11,5 & 4 & 4,2 & 0 & 0 & 30 & 31,3 & \\
\hline Enough & 14 & 14,6 & 8 & 8,3 & 0 & 0 & 1 & 1 & 23 & 24 & \\
\hline $\begin{array}{l}\text { Lack of } \\
\text { knowledge }\end{array}$ & 39 & 40,6 & 4 & 4,2 & 0 & 0 & 0 & 0 & 43 & 44,8 & 0,000 \\
\hline Amount & 68 & 70,8 & 23 & 24 & 4 & 4,2 & 1 & 1 & 96 & 100 & \\
\hline
\end{tabular}

Based on table 2 showed that almost half of the respondents had a lack of knowledge of nutrition $(40,6 \%)$ but there is good knowledge of nutrition in mild anaemia $(11,5 \%)$. The statistic test using rho spearman was obtained at 0,000 which $p$-value $<0,05$ that can be concluded if there are the relationship between knowledge of nutrition and the incidence of anaemia in teenager in $\mathrm{Al}$ Ma'ruf Islamic Boarding School Kediri in 2020. 


\section{STRADA Jurnal Ilmiah Kesehatan}

DOI: $10.30994 /$ sjik.v9i2.460

ISSN: 2252-3847 (print); 2614-350X (online)

Vol.9 No.2 November 2020 Page.1291-1299

The relationship between physical activity and the incidence of anaemia in a teenager

Table 3 The relationship between physical activity and the incidence of anaemia in a teenager

\begin{tabular}{|c|c|c|c|c|c|c|c|c|c|c|c|}
\hline \multirow{3}{*}{$\begin{array}{l}\text { Physical } \\
\text { activity }\end{array}$} & \multicolumn{10}{|c|}{ Incidence of anaemia } & \multirow{3}{*}{$\mathrm{p}$ value } \\
\hline & \multicolumn{2}{|c|}{ Not anaemia } & \multicolumn{2}{|c|}{ Mild anaemia } & \multicolumn{2}{|c|}{$\begin{array}{l}\text { Moderate } \\
\text { anaemia }\end{array}$} & \multicolumn{2}{|c|}{$\begin{array}{c}\text { Severe } \\
\text { anaemia }\end{array}$} & \multicolumn{2}{|c|}{ Total } & \\
\hline & $\mathrm{N}$ & $\%$ & $\mathrm{~N}$ & $\%$ & $\mathrm{~N}$ & $\%$ & $\mathrm{~N}$ & $\%$ & $\mathrm{~N}$ & $\%$ & \\
\hline Mild & 35 & 36,5 & 5 & 5,2 & 0 & 0 & 1 & 1 & 41 & 42,7 & \multirow{4}{*}{0,002} \\
\hline Moderate & 19 & 19,8 & 6 & 6,3 & 2 & 2,1 & 0 & 0 & 27 & 28,1 & \\
\hline Severe & 14 & 14,6 & 12 & 12,5 & 2 & 2,1 & 0 & 1 & 28 & 29,2 & \\
\hline Amount & 68 & 70,8 & 23 & 24 & 4 & 4,2 & 1 & 1 & 96 & 100 & \\
\hline
\end{tabular}

Based on table 3 showed that almost half of the respondents $(36,5 \%)$ had mild physical activity. The statistic test using rho spearman was obtained at 0,002 which pvalue $<0,05$ that can be concluded if there are the relationship between physical activity and the incidence of anaemia in a teenager in Al Ma'ruf Islamic Boarding School Kediri in 2020.

\section{The relationship between nutritional status and the incidence of anaemia in a teenager}

Table 4 The relationship between nutritional status and the incidence of anaemia in a teenager

\begin{tabular}{|c|c|c|c|c|c|c|c|c|c|c|c|}
\hline \multirow{3}{*}{$\begin{array}{l}\text { Nutritional } \\
\text { Status }\end{array}$} & \multicolumn{10}{|c|}{ Incidence of anaemia } & \multirow{3}{*}{$\mathrm{p}$ value } \\
\hline & \multicolumn{2}{|c|}{ Not anaemia } & \multicolumn{2}{|c|}{ Mild anaemia } & \multicolumn{2}{|c|}{$\begin{array}{c}\text { Moderate } \\
\text { anaemia }\end{array}$} & \multicolumn{2}{|c|}{$\begin{array}{c}\text { Severe } \\
\text { anaemia }\end{array}$} & \multicolumn{2}{|c|}{ Total } & \\
\hline & $\mathrm{N}$ & $\%$ & $\mathrm{~N}$ & $\%$ & $\mathrm{~N}$ & $\%$ & $\mathrm{~N}$ & $\%$ & $\mathrm{~N}$ & $\%$ & \\
\hline Thin & 7 & 7,3 & 23 & 24 & 1 & 1 & 0 & 0 & 31 & 32,3 & \multirow{4}{*}{0,000} \\
\hline Normal & 55 & 57,3 & 0 & 0 & 3 & 3,1 & 0 & 0 & 58 & 60,4 & \\
\hline Fat & 6 & 6,3 & 0 & 0 & 0 & 0 & 1 & 1 & 7 & 7,3 & \\
\hline Amount & 68 & 70,8 & 23 & 24 & 4 & 4,2 & 1 & 1 & 96 & 100 & \\
\hline
\end{tabular}

Based on table 4 showed that most of the respondents $(57,3 \%)$ had a normal nutritional status. The respondent who had anaemia, $24 \%$ had a thin body in nutritional status. The statistic test using rho spearman was obtained at 0,000 which p-value $<0,05$ that can be concluded if there are the relationship between nutritional status and the incidence of anaemia in a teenager in Al Ma'ruf Islamic Boarding School Kediri in 2020

\section{The relationship between the length of menstruation and the incidence of anaemia in a teenager}

Table 5 The relationship between length of menstruation and the incidence of anaemia in a teenager

\begin{tabular}{|c|c|c|c|c|c|c|c|c|c|c|c|}
\hline \multirow{3}{*}{$\begin{array}{l}\text { Length of } \\
\text { menstruation }\end{array}$} & \multicolumn{10}{|c|}{ Incidence of anaemia } & \multirow[t]{3}{*}{$\mathrm{p}$ value } \\
\hline & \multicolumn{2}{|c|}{ Not anaemia } & \multicolumn{2}{|c|}{ Mild anaemia } & \multicolumn{2}{|c|}{$\begin{array}{c}\text { Moderate } \\
\text { anaemia }\end{array}$} & \multicolumn{2}{|c|}{$\begin{array}{c}\text { Severe } \\
\text { anaemia }\end{array}$} & \multicolumn{2}{|c|}{ Total } & \\
\hline & $\mathrm{N}$ & $\%$ & $\mathrm{~N}$ & $\%$ & $\mathrm{~N}$ & $\%$ & $\mathrm{~N}$ & $\%$ & $\mathrm{~N}$ & $\%$ & \\
\hline Hipomenorhoe & 24 & 25 & 5 & 5,2 & 1 & 1 & 0 & 0 & 30 & 31,3 & 0,071 \\
\hline
\end{tabular}




\section{STRADA Jurnal Ilmiah Kesehatan}

DOI: $10.30994 /$ siik.v9i2.460

ISSN: 2252-3847 (print); 2614-350X (online)

Vol.9 No.2 November 2020 Page.1291-1299

\begin{tabular}{lcccccccccc}
\hline Normal & 42 & 43,8 & 17 & 17,7 & 1 & 1 & 1 & 1 & 61 & 63,5 \\
Hipermenorhoe & 2 & 2,1 & 1 & 1 & 2 & 2,1 & 0 & 0 & 5 & 5,2 \\
\hline Amount & 68 & 70,8 & 23 & 24 & 4 & 4,2 & 1 & 1 & 96 & 100 \\
\hline
\end{tabular}

Based on table 5 showed that most of the respondents $(43,83 \%)$ had a normal length of menstruation. The statistic test using rho spearman was obtained at 0,071 which p-value $>0,05$ that can be concluded if there is no relationship between the length of menstruation and the incidence of anaemia in a teenager in Al Ma'ruf Islamic Boarding School Kediri in 2020 .

The factor that influenced the incidence of anaemia in a teenager

Table 5 The result of statistical analysis

\begin{tabular}{lcccccc}
\hline & \multicolumn{3}{c}{} & \multicolumn{3}{c}{ 95\% C.I for EXP(B) } \\
\cline { 2 - 7 } & B & S.E. & Sig & $\operatorname{Exp}(\mathrm{B})$ & Lower & Upper \\
\hline Age & 1,963 & 0,869 & 0,024 & 7,118 & 1,295 & 39,113 \\
Knowledge of nutrition & $-1,472$ & 0,53 & 0,006 & 0,230 & 0,081 & 0,649 \\
Physical activity & 0,231 & 0,445 & 0,604 & 1,259 & 0,527 & 3,010 \\
Nutritional status & $-3,703$ & 0,858 & 0,000 & 0,025 & 0,537 & 9,277 \\
Constant & 0,443 & 3,315 & 0,270 & 1,558 & & \\
\hline
\end{tabular}

Based on multiple regression logistic statistical test, there are found that age (p value $=0,024, \mathrm{OR}=7,118)$, knowledge of nutrition $(0,006, \mathrm{OR}=0,230)$ and nutritional status ( $\mathrm{p}$ value $=0,000, \mathrm{OR}=0,025)$ were have correlation together with the incidence of anaemia. Only physical activity that has no correlation with the incidence of anaemia ( $p$ value $=0,604)$.

\section{DISCUSSION}

\section{The Relationship between age and incidence of anaemia in a teenager}

Based on table 1 showed that almost half of the respondents $(43,8 \%)$ did not have anaemia in late teenage. The result of a statistic test using rho spearman obtained that $\mathrm{p}$ value is 0,017 which $\mathrm{p}$-value $<0,05$ that can be concluded if there are the relationship between age and the incidence of anaemia in a teenager in Al Ma'ruf Islamic Boarding School Kediri in 2020.

Teenager or adolescence is a critical period of increased nutritional demand for development, often coupled with behavioural challengers and reduced dietary intake and quality, and therefore warrants careful consideration (Abioye \& Fawzi, 2020).

Based on data, most of the respondent is in a late teen. Late teen is the transitional age becoming an adult. In this phase, someone can think more deep and good to choose the better thing in their life especially to consumed nutrition that needed by the body.

\section{The relationship between knowledge of nutrition and the incidence of anaemia in a teenager}

Based on table 2 showed that almost half of the respondents had a lack of knowledge of nutrition $(40,6 \%)$ but there is good knowledge of nutrition in mild anaemia $(11,5 \%)$. The statistic test using rho spearman was obtained at 0,000 which p-value $<0,05$ that can be concluded if there are the relationship between knowledge of nutrition and the incidence of anaemia in a teenager in Al Ma'ruf Islamic Boarding School Kediri in 2020. 


\section{STRADA Jurnal Ilmiah Kesehatan}

DOI: $10.30994 /$ sjik.v9i2.460

ISSN: 2252-3847 (print); 2614-350X (online)

Vol.9 No.2 November 2020 Page.1291-1299

The results of this study are corroborated by Ambarwati's (2017) research that knowledge of nutrition affected the incident of anaemia (Ambarwati \& Pangesti, 2017). A good level of nutrition knowledge will make someone know about the nutritional needs of the body and be able to take precautions to avoid anaemia.

Anggoro's research in Senior High School's student showed that there is a correlation between knowledge of nutrition with an incident of anaemia (Anggoro, 2020). Notoadmodjo said that knowledge will influence a person's attitude and behaviour (Soekidjo Notoadmodjo, 2010). If the knowledge of nutrition is good, then the attitude in choosing foods that contain nutrients will be correct and will consume food needed by the body. Yunita's research about knowledge of iron consumption correlates with the incidence of anaemia. It has bigger risk up to 13,5 times influence the anaemia. (Yunita et al., 2020)

The important thing that the respondent in this study lived in Islamic Boarding School. Automatically have similar nutrition to consumed every day. So, teachers who became a role model of them having behaviour for dietary habit. Such as Panyuluh' study said that teacher's attitude and behaviour can influence the student in Islamic Boarding School to get prevention of anaemia.(Panyuluh, Nugraha, \& Riyanti, 2018). So, there should be more education to the teacher as a role model for the student.

\section{The relationship between physical activity and the incidence of anaemia in a teenager}

Based on table 3 showed that almost half of the respondents $(36,5 \%)$ had mild physical activity. The statistic test using rho spearman was obtained at 0,002 which pvalue $<0,05$ that can be concluded if there are the relationship between physical activity and the incidence of anaemia in a teenager in Al Ma'ruf Islamic Boarding School Kediri in 2020.

The result of this study is reinforced by the research study which shows that teenagers who have light physical activity will increase the risk of anaemia, even though the statistical test result is not significant (Permaesih \& Herman, 2015). Annisa with her study in Semarang showed there no correlation between physical activity with incidence of anaemia because most of the respondent is lazy to do physical activity (Annisa, Rahfiludin, \& Siti Fatimah, 2018). But in this study, most of the respondent who had no anaemia usually doing mild physical activity. And most of the respondents who get anaemia usually doing severe physical activity.

\section{The relationship between nutritional status and the incidence of anaemia in a teenager}

Based on table 4 showed that most of the respondents $(57,3 \%)$ had a normal nutritional status. A respondent who had anaemia, $24 \%$ had a thin body in nutritional status. The statistic test using rho spearman was obtained at 0,000 which p-value $<0,05$ that can be concluded if there are the relationship between nutritional status and the incidence of anaemia in a teenager in Al Ma'ruf Islamic Boarding School Kediri in 2020.

Nutritional status is a reflection of sufficient nutritional consumption. One of the anthropometric measurements to determine nutritional status is to measure the body weight and height called Body mass index (BMI). This measurement model is better than the other measurement model (Supariasa, Backri, \& ibnu fajar, 2012).

Based on this research there are one respondent who had severe anaemia had fat nutritional status. The reduction of $\mathrm{Hb}$ levels points at overweight as a risk factor for the development (Viana, Raggio, \& Valeria, 2013). Nutritional status related to a teenager's 


\section{STRADA Jurnal Ilmiah Kesehatan}

DOI: $10.30994 /$ sjik.v9i2.460

ISSN: 2252-3847 (print); 2614-350X (online)

Vol.9 No.2 November 2020 Page.1291-1299

lifestyle. Based on Hasan's Research, a teenager's lifestyle like a dietary habit and skip breakfast can improve the incident of anaemia. (Nasir \& Hassan, 2014).

Based on this research there are one respondent who had severe anaemia had fat nutritional status. The reduction of $\mathrm{Hb}$ levels points at overweight as a risk factor for the development (Viana et al., 2013). Nutritional status related to a teenager's lifestyle. Based on Hasan's Research, a teenager's lifestyle like a dietary habit and skip breakfast can improve the incident of anaemia.(Nasir \& Hassan, 2014).

Although there is no correlation between nutritional status with the incidence of anaemia, there is a correlation with iron consumption (Tanziha, Utama, \& Rosmiati, 2016). Wibowo's study also correlated with nutritional status with the incidence of anaemia (Daris, Wibowo, Notoatmojo, \& Rohmani, 2013) like Shara's study also showed that nutritional status can influence the incidence of anaemia in a teenager. (El Shara, Wahid, \& Semiarti, 2017)

One of the benefits lived in Islamic Boarding School is the pattern of consumed nutrition almost the same. Especially breakfast is a must if we stay in boarding school. As the study of Jaelani (2018), there is a correlation between breakfast habit with the incidence of anaemia in junior high school student (Jaelani, Simanjuntak, \& Yuliantini, 2018).

\section{The relationship between length of menstruation and the incidence of anaemia in teenager}

Based on table 5 showed that most of the respondents $(43,83 \%)$ had a normal length of menstruation. The statistic test using rho spearman was obtained at 0,071 which p-value $>0,05$ that can be concluded if there is no relationship between the length of menstruation and the incidence of anaemia in a teenager in Al Ma'ruf Islamic Boarding School Kediri in 2020

Based on the result of Kumalasari's study (2019) regarding menstrual patterns with the incidence of anaemia in a teenager, it was found that menstrual patterns influenced the incidence of anaemia. An abnormal menstrual pattern has a chance of 8,8886 times that young woman experience anaemia compared to teenager girls who have normal menstrual patterns. Abnormal menstrual patterns in this study experienced menstrual lengths that exceeded normal so that the blood came out more than normal (Kumalasari, Kameliawati, Mukhlis, \& Kristanti, 2019). Agustina's research also showed that the length of menstruation influenced the incident of anaemia in teenager (Agustina \& Diani, 2017). Contrast to the results of this study that teenagers who got anaemia had normal menstrual periods. In this opinion that there are other factors which more affected to anaemia.

\section{Factor that influenced the incidence of anaemia in a teenager}

Based on multiple regression logistic statistical test, there are found that age ( $\mathrm{p}$ value $=0,024, \mathrm{OR}=7,118)$, knowledge of nutrition $(0,006, \mathrm{OR}=0,230)$ and nutritional status ( $\mathrm{p}$ value $=0,000, \mathrm{OR}=0,025)$ were have correlation together with the incidence of anaemia. Only physical activity that has no correlation with the incidence of anaemia $(p$ value $=0,604)$.

There is no correlation between physical activity if the factor using together because physical activity measure just only a moment time, hadn't measured in a long time and every respondent had some different activity in someday. 


\section{STRADA Jurnal Ilmiah Kesehatan}

DOI: $10.30994 /$ sjik.v9i2.460

ISSN: 2252-3847 (print); 2614-350X (online)

Vol.9 No.2 November 2020 Page.1291-1299

\section{CONCLUSION}

The conclusion of this research showed factor that influenced the incident of anaemia are age $(\mathrm{OR}=7,118)$, knowledge of nutrition $(\mathrm{OR}=0,230)$ and nutritional status $(\mathrm{OR}=0,025)$. Age is the most affected factor that increasing the incident of anaemia.

\section{REFERENCES}

Abioye, A. I., \& Fawzi, W. W. (2020). Chapter 27 - Nutritional anemias. In Present Knowledge in Nutrition. https://doi.org/10.1016/B978-0-12-818460-8.00027-7

Agustina, R., \& Diani, N. (2017). Faktor-faktor yang berhubungan dengan kejadian anemia pada remaja putri. Dunia Keperawatan, 5(3), 1-10.

Ambarwati, D., \& Pangesti, wilis dwi. (2017). MUHAMMADIYAH PURWOKERTO THE ANALYSIS OF AFFECTING FACTORS OF ANEMIA IN STUDENTS OF DIPLOMA MIDWIFERY PROGRAM OF STUDY AT HEALTH SCIENCE Banyumas, Angka kejadian anemia remaja sebesr $86,5 \%$. Sejalan dengan hasil observasi yang. 4(2), 2301-6213.

Anggoro, S. (2020). Faktor-faktor yang mempengaruhi kejadian anemia pada siswi sma. 10(3), 341-350.

Annisa, A., Rahfiludin, Z., \& Siti Fatimah. (2018). Hubungan antara kejadian anemia dengan aktivitas fisik dan riwayat penyakit infeksi pada siswi kelas XI SMA negeri 11 Semarang. Jurnal Kesehatan Masyarakat (e-Jurnal), 6(5), 311-316.

Beck, K. L., \& Zealand, N. (2016). Anemia: Prevention and Dietary Strategies. In Encyclopedia of Food and Health (1st ed.). https://doi.org/10.1016/B978-0-12384947-2.00030-1

Daris, C., Wibowo, T., Notoatmojo, H., \& Rohmani, A. (2013). Hubungan Antara Status Gizi dengan Anemia pada Remaja Putri di Sekolah Menengah Pertama Muhammadiyah 3 Semarang Relationship Between Nutritional Status With Anemia in Young Women in Junior High School of Muhammadiyah 3 Semarang. 1, 3-7.

El Shara, F., Wahid, I., \& Semiarti, R. (2017). Hubungan Status Gizi dengan Kejadian Anemia pada Remaja Putri di SMAN 2 Sawahlunto Tahun 2014. Jurnal Kesehatan Andalas, 6(1), 202. https://doi.org/10.25077/jka.v6i1.671

Jaelani, M., Simanjuntak, betty yosephin, \& Yuliantini, E. (2018). Faktor- Faktor Yang Berhubungan Dengan Kejadian Anemia Pada Remaja Putri. Nursing Arts, 12(2), 7890. https://doi.org/10.36741/jna.v12i2.78

Kotwal, A. (2016). Current Medicine Research and Practice Iron deficiency anaemia among children in South East Asia: Determinants, importance, prevention and control strategies. Indian Journal of Rheumatology, 6(3), 117-122. https://doi.org/10.1016/j.cmrp.2016.05.009

Kumalasari, D., Kameliawati, F., Mukhlis, H., \& Kristanti, D. A. (2019). Pola Menstruasi dengan kejadian anemia pada remaja. Wellness and Healthy Magazine, 1(2), 187192.

Nasir, N., \& Hassan, A. (2014). University female students. Journal of Microscopy and Ultrastructure. https://doi.org/10.1016/j.jmau.2014.11.003

Panyuluh, dhenok citra, Nugraha, P., \& Riyanti, E. (2018). Faktor faktor yang berhubungan dengan perilaku penyebab anemia pada santriwati pondok pesantren Darul Ulum Kabupaten Kendal. 6(April), 156-162.

Pennesi, C. M., Rominski, S. D., Rosen, M. W., Odukoya, E. J., Weyand, A. C., Quint, E. H., ... Wilson, E. (2019). 78. Large Prolapsing Uterine Fibroid and Severe Anemia in a Teenager: A Case Report. Journal of Pediatric and Adolescent Gynecology, 32(2), 


\section{STRADA Jurnal Ilmiah Kesehatan}

DOI: $10.30994 /$ sjik.v9i2.460

ISSN: 2252-3847 (print); 2614-350X (online)

Vol.9 No.2 November 2020 Page.1291-1299

226-227. https://doi.org/10.1016/j.jpag.2019.02.080

Permaesih, D., \& Herman, S. (2015). FAKTOR-FAKTOR YANG MEMPENGARUHI ANEMIA PADA REMAJA. 33(4), 11-14.

RISKESDAS. (2018). Hasil Utama Riset Kesehatan Dasar. Kementrian Kesehatan Republik Indonesia, 1-100. https://doi.org/1 Desember 2013

Shamah, T., Villalpando, S., \& Cruz, V. De. (2017). Anemia. 1, 103-112. https://doi.org/10.1016/B978-0-12-803678-5.00018-7

Shubham, K., Anukiruthika, T., Dutta, S., Kashyap, A. V, Moses, J. A., \& Anandharamakrishnan, C. (2020). Trends in Food Science \& Technology Iron de fi ciency anemia: A comprehensive review on iron absorption, bioavailability and emerging food forti fi cation approaches. 99(March), 58-75. https://doi.org/10.1016/j.tifs.2020.02.021

Soekidjo Notoadmodjo. (2010). Ilmu Perilaku Kesehatan. jakarta: Rineka Cipta.

Supariasa, i dewa nyoman, Backri, B., \& ibnu fajar. (2012). penilaian status gizi. jakarta: EGC.

Tanziha, I., Utama, L. J., \& Rosmiati, R. (2016). Faktor Risiko Anemia Ibu Hamil Di Indonesia. 11(2), 143-152. https://doi.org/10.25182/jgp.2016.11.2.\%p

Viana, U., Raggio, R., \& Valeria, G. (2013). Overweight is associated with low hemoglobin levels in adolescent girls. Obesity Research \& Clinical Practice, 7(3), e218-e229. https://doi.org/10.1016/j.orcp.2011.12.004

Villalpando, S. (2016). Anemia: Causes and Prevalence. 156-163. https://doi.org/10.1016/B978-0-12-384947-2.00029-5

Wall, C., Gillies, N., \& Zealand, N. (2019). Nutritional Anemias. 776-792. https://doi.org/10.1016/B978-0-128-12735-3/00127-8

Yunita, F. A., Parwatiningsih, S. A., Hardiningsih, M., Nurma Yuneta, A. E., Kartikasari, M. N. D., \& Ropitasari, M. (2020). Hubungan Pengetahuan Remaja Putri Tentang Konsumsi Zat Besi Dengan Kejadian Anemia Di Smp 18 Surakarta. PLACENTUM: Jurnal Ilmiah Kesehatan Dan Aplikasinya, 8(1), 36. https://doi.org/10.20961/placentum.v8i1.38632 